\title{
Virulence and Simple Sequence Repeat Marker Segregation in a Puccinia striiformis f. sp. tritici Population Produced by Selfing a Chinese Isolate on Berberis shensiana
}

\author{
Yuan Tian, Gangming Zhan, Xianming Chen, Angkana Tungruentragoon, Xia Lu, Jie Zhao, \\ Lili Huang, and Zhensheng Kang
}

First, second, fourth, fifth, sixth, seventh, and eighth authors: State Key Laboratory of Crop Stress Biology for Arid Areas and College of Plant Protection, Northwest A\&F University, Yangling, Shaanxi 712100, P. R. China; and third author: USDA-ARS, Wheat Health, Genetics, and Quality Research Unit, and Department of Plant Pathology, Washington State University, Pullman 99164-6430.

Accepted for publication 3 November 2015.

\begin{abstract}
Tian, Y., Zhan, G. M., Chen, X. M., Tungruentragoon, A., Lu, X., Zhao, J., Huang, L. L., and Kang, Z. S. 2016. Virulence and simple sequence repeat marker segregation in a Puccinia striiformis f. sp. tritici population produced by selfing a Chinese isolate on Berberis shensiana. Phytopathology 106:185-191.

Puccinia striiformis f. sp. tritici, the causal agent of wheat stripe rust, frequently produces new races overcoming resistance in wheat cultivars. A recently identified race, V26 with virulence to $Y r 26$ and many other stripe rust resistance genes, has a high potential to cause epidemics in China. In this study, teliospores from a single-urediniospore isolate of V26 (Pinglan 17-7) produced on the wheat line 92R137 ( $\mathrm{rr26}$ ) were used to produce a sexual population through selfing by infecting Berberis shensiana plants under controlled conditions. One hundred and eighteen progeny isolates and the parental isolate were phenotyped for virulence/avirulence

on $24 \mathrm{Yr}$ gene lines of wheat. These progeny isolates were all avirulent to $Y r 5, Y r 8, Y r 15$, and $Y r T r 1$ and virulent to $Y r 1, Y r 2, Y r 7, Y r 9, Y r 10, Y r 17$, $Y r 24, Y r 25, Y r 26, Y r A, Y r E x p 2$, and YrV23, indicating that the parental isolate is homozygous avirulent or homozygous virulent at these loci. The progeny population segregated for avirulence to $\mathrm{Yr} 6, \mathrm{Yr} 43$, and $\mathrm{YrSP}$ at one locus (3 avirulent:1 virulent ratio); for virulence to $Y r 27$ and $Y r 28$ at one locus ( 3 virulent: 1 avirulent); and for $Y r 4, Y r 32$, and $Y r 44$ at two loci (15 virulent: 1 avirulent). Among the eight segregating avirulence/virulence loci, association was found between virulence to $Y r 4$ and $Y r 32$, as well as between virulence to $Y r 6$ and $Y r 43$ based on $\chi^{2}$ tests. From 82 genotypically different progeny isolates, 24 pathotypes and 82 multilocus genotypes were identified. The results show that a highly diverse population can be produced from a single isolate by selfing on a barberry plant and sexually produced population can be used to genetically characterize virulence of the stripe rust pathogen.
\end{abstract}

Stripe rust, caused by Puccinia striiformis Westend. f. sp. tritici Erikss., is one of the most important diseases on wheat worldwide (Chen 2005; Wellings 2011). It causes great losses of yield every year in China. When severe epidemics occur nationwide, as in 1950, 1964, 1990, and 2002, yield losses can exceed one million tons (Chen et al. 2009b; Wan et al. 2004, 2007). In addition, chemicals are heavily used to reduce yield losses, adding huge costs for wheat production. The best way for controlling stripe rust is growing resistant cultivars. However, "breakdown" of resistance appears frequently due to virulence changes in the pathogen population (Chen et al. 2009b; Li 1980; Wan et al. 2004). The P. striiformis f. sp. tritici population changes may be caused by mutation, introduction, genetic drift, asexual and/or sexual recombination, and host selection (Chen 2005; Gassner and Straib 1932; Godard 1976; Little and Manners 1967; Park and Wellings 2012).

Compared with the low genetic diversity in the European and Australian populations, the Chinese $P$. striiformis f. sp. tritici population has a relatively high diversity (Duan et al. 2010; Mboup et al. 2009). Furthermore, the rate of genetic recombination and

Corresponding authors: Z. S. Kang; E-mail address: kangzs@nwsuaf.edu.cn L. L. Huang; E-mail address: huanglili@nwsuaf.edu.cn

The first two authors contributed equally to this work.

*The $\boldsymbol{e}$-Xtra logo stands for "electronic extra" and indicates that four supplementary tables are published online.

http://dx.doi.org/10.1094/PHYTO-07-15-0162-R

(C) 2016 The American Phytopathological Society ability to produce teliospores of $P$. striiformis f. sp. tritici in China are higher than those in European countries and Australia, leading to speculation of the existence of a sexual or parasexual cycle in P. striiformis f. sp. tritici in China (Ali et al. 2010; Mboup et al. 2009). The populations of sexual pathogens usually exhibit a relatively high degree of diversity compared with asexual pathogens, and pathogens that have a mixed reproduction system pose the greatest risk of circumventing resistance genes (McDonald and Linde 2002). Crossing experiments in greenhouse confirmed that new races of the wheat stem rust pathogen ( $P$. graminis $\mathrm{f}$. $\mathrm{sp}$. tritici) could be produced on Berberis spp. (Newton et al. 1930; Waterhouse 1929). Since Berberis spp. was found as alternate hosts of $P$. striiformis f. sp. tritici (Jin et al. 2010), sexual reproduction of the pathogen has become a focus of attention. Zhao et al. (2011) inoculated barberry plants using P. striiformis f. sp. tritici teliospores, and reported 18 Berberis spp. as alternate hosts for $P$. striiformis $\mathrm{f}$. sp. tritici in China. A large number of Berberis species distribute widely in China and commonly adjacent to wheat fields. In addition, high virulence diversity on wheat was found among 200 single-uredinium isolates derived from 20 P. striiformis f. sp. tritici isolates collected from naturally infected barberry plants in China (Wang et al. 2015b; Zhao et al. 2013). In the United States, 16 races were identified from 29 urediniospore isolates obtained through selfing one isolate of $P$. striiformis $\mathrm{f}$. sp. tritici under controlled conditions (Wang et al. 2012). A similar study obtained 16 isolates with different virulence patterns from selfing a European isolate (Rodriguez-Algaba et al. 2014). These studies indicate that sexual reproduction may play an important role in generating genetic diversity of $P$. striiformis f. sp. tritici. However, the key mechanism responsible for $P$. striiformis f. sp. tritici virulence changes in China is still unclear. 
The gene-for-gene relationship implies that the pathogenicity genotype of a pathogen isolate can be determined through studying the infection patterns of its progeny isolates on host lines harboring different resistance genes (Flor 1965). Resistance genes encode putative receptors that respond to the products of $A v r$ genes ( $A v r$, avirulence) produced by the pathogen during infection (McDowell and Woffenden 2003). From the segregation rate of S1 progeny though selfing, we could determine the heterozygosity, inheritance of virulence, and linkage relationships of genes for pathogenicity. Early studies on genetics of rust fungi were mainly on those causing leaf rust and stem rust of wheat and crown rust of oat as their alternate hosts were known (Statler 1977, 1979, 1985, 1990). Such studies were not possible for $P$. striiformis $\mathrm{f}$. sp. tritici as its alternate hosts were discovered just recently (Jin et al. 2010; RodriguezAlgaba et al. 2014; Wang and Chen 2013, 2015). Selfing experiments of $P$. triticina and Melampsora lini were conducted to determine heterozygosity, inheritance of virulence, and linkage relationships of genes for pathogenicity, and a single gene or two genes segregated for virulence/avirulence (Statler 1977, 1979, 1990, 2000). Using random amplified polymorphic DNA and amplified fragment length polymorphic markers to analyze two parental isolates and their hybrid progeny isolates of $P$. graminis $\mathrm{f}$. sp. tritici, Zambino et al. (2000) identified molecular markers and constructed genetic maps containing avirulence genes AvrT6, AvrT8a, AvrT9a, AvrT10, AvrT21, AvrT28, AvrT30, and AvrTU. So far, neither molecular markers nor linkage relationship have been reported for avirulence genes in $P$. striiformis $\mathrm{f}$. sp. tritici.

As Puccinia species are dikaryotic in their asexual uredinial stage, the information on heterozygosity or homozygosity of virulence/avirulence loci is important for predicting potential virulence changes based on the existing populations. There is high heterozygosity in the leaf rust pathogen ( $P$. triticina) (Samborski and Dyck 1976; Statler 1977). Because virulence variation would happen in a heterozygous population more rapidly than in a homozygous population (Statler 1977), it is important to survey the $P$. striiformis f. sp. tritici uredinial allelic variation at the virulence/avirulence loci, which would contribute significantly toward a rational layout of regional resistance genes through resistance breeding. High genome heterozygosity has been shown for $P$. striiformis f. sp. tritici based on molecular markers, allelic sequences, and genomic sequences (Cheng and Chen 2014; Liu et al. 2012; Zheng et al. 2013). However, direct evidence of virulence/avirulence heterozygosity is still missing for the lack of selfing or crossing experiment on alternate hosts.

The discovery of Berberis spp. as alternate hosts for $P$. striiformis f. sp. tritici made it possible to study the genetics of virulence of $P$. striiformis f. sp. tritici by selfing and making crosses. The inheritance of virulence/avirulence studies of $P$. striiformis $\mathrm{f}$. $\mathrm{sp}$. tritici have been initiated by Wang et al. (2012) in the United States and by Rodriguez-Algaba et al. (2014) in Europe. The results of these early studies were limited by the small number of progeny isolates. In the present study, we developed a sexual population by selfing isolate Pinglan 17-7, representing an emerging P. striiformis f. sp. tritici race, V26 with virulence to Yr26 (Han et al. 2015; Zhan et al. 2015), on barberry plants. The objectives of this study was to determine homozygosity and heterozygosity of virulence/avirulence loci corresponding to various $Y r$ genes including $Y r 26$, determine the inheritance of virulence/avirulence genes, and estimate the genetic diversity for a sexual population derived from a single isolate using simple sequence repeat (SSR) markers. The information should be useful for understanding the $P$. striiformis f. sp. tritici variations in China and provide a genetic basis for selecting genes for developing wheat cultivars with relatively durable resistance.

\section{MATERIALS AND METHODS}

Urediniospore multiplication and teliospore production. The parental isolate, Pinglan 17-7 collected from Gansu Province in
2013, was identified as V26 (virulent to Yr26), an emerging $P$. striiformis f. sp. tritici race posing a great threat to wheat production in China (Han et al. 2015; Zhan et al. 2015). This isolate was multiplied from a single urediniospore obtained from a symptomatic leaf tissue of the wheat cultivar 92R137 with $\operatorname{Yr} 26$. Teliospores were produced by inoculating urediniospores of the isolate on 92R137 adult plants. The wheat plants inoculated with urediniospores were kept for $24 \mathrm{~h}$ at $10^{\circ} \mathrm{C}$ in a dew chamber in dark, and then grown in a growth chamber at $16^{\circ} \mathrm{C}$ with a $16 / 8 \mathrm{~h}$ light/dark cycle. When infection reached heavy sporulation of uredinia on the leaves, the temperature was increased to $25^{\circ} \mathrm{C}$ in daylight and $16^{\circ} \mathrm{C}$ at night to speed up telia formation (Zheng 2011). Telia formed about 1 month after urediniospore inoculation. The leaves with teliospores were dried at room temperature for 2 days and then put in paper bags kept in a desiccator at $4^{\circ} \mathrm{C}$.

Inoculation of barberry with germinated teliospores. Seedlings of barberry (B. shensiana) used for inoculation were grown in pots in a greenhouse. Teliospores were germinated following the method described by Zhao et al. (2013). When abundant basidiospores were observed, the petri dish containing wheat leaf segments with germinating teliospores was placed upside down on the top of the plastic cylinder surrounding the barberry plant, which was kept for 3 to 4 days in a dew chamber with a dark/light and temperature cycle of $12 \mathrm{~h}$ dark at $12^{\circ} \mathrm{C}$, and $12 \mathrm{~h}$ light at $16^{\circ} \mathrm{C}, 100 \%$ relatively humidity $(\mathrm{RH})$. After incubation, the inoculated plants were moved to a growth chamber with the same temperature and light conditions, $75 \% \mathrm{RH}$.

Selfing of the parental isolate. The barberry plant was put in a chamber with $90 \%$ RH when pycnia appeared (usually at 7 days postinoculation). When nectar that contains pycniospores appeared (usually 3 to 5 days after the appearance of a pycnium), crosses were made by transferring nectar from one pycnium to another with a toothpick that had been soaked in sterile water for several hours. Finally aecia appeared at 5 to 7 days after crossing.

Development of uredinial progeny isolates. Two methods were used to get aeciospores from a single aecium when the cups were 2 to $3 \mathrm{~mm}$ in length. The first method was gently tapping a barberry leaf with only one cup from a well-developed aecium over a glass slide. The second method was cutting a cluster of cups from an aecium, and the cups were pressed gently on a glass slide. Oneleaf seedlings of wheat variety Mingxian 169, which is susceptible to all Chinese races of $P$. striiformis $\mathrm{f}$. $\mathrm{sp}$. tritici, were inoculated with aeciospores to produce uredinial isolates. After gently removing wax from wheat seedling leaves and misting the leaves with water, individual aeciospores were picked from the slide under a stereomicroscope and transferred onto wheat leaves with a fine glass. One leaf was inoculated with only one aeciospore. The inoculated wheat plants were kept for $24 \mathrm{~h}$ at $10^{\circ} \mathrm{C}$ in a dew chamber without light. After incubation, plants were grown in a growth chamber at $16^{\circ} \mathrm{C}$ with $16 / 8 \mathrm{~h}$ light/dark cycle. When lesions started appearing, successfully inoculated plants were separated into different pots, if two or more plants in one pot were infected. Plots were isolated by plastic booths to prevent cross-contamination. Urediniospores produced on each leaf were collected with a glass test tube and stored in a desiccator at $4{ }^{\circ} \mathrm{C}$. Urediniospores were multiplied on seedlings of the same wheat variety to produce enough quantity for virulence tests and DNA extraction.

Virulence tests. The parental isolate and progeny isolates were tested for virulence phenotypes (VPs) on a set of 24 wheat genotypes, most of which are near-isogenic lines in the "Avocet Susceptible' background (Supplementary Table S1). Mingxian 169 and 92R137 (Yr26) were used as susceptible controls. The procedures and conditions for growing and inoculating plants were described previously (Zhan et al. 2012). Infection types (ITs) were detected 18 to 20 days after inoculation based on a 0 to 9 scale as described by Line and Qayoum (1992). ITs 0 to 5 were considered avirulent (A) and 6 to 9 virulent (V). Virulence phenotyping was repeated twice for all isolates. For genetic analysis, the progeny 
isolates produced by selfing were considered as $\mathrm{F}_{2}$ generation, and the heterokaryotic urediniospores were considered as diploid. $\chi^{2}$ tests were used to determine the goodness of fit of observed numbers to theoretical segregation ratios for both virulence and SSR markers. The number of VPs was determined using VAT 1.0 software (Kosman and Leonard 2007).

DNA extraction. DNA was extracted from urediniospores using the method described by Aljanabi and Martinez (1997) with modifications. Urediniospores were transferred to a 1.5-ml centrifuge tube, sterilized silica sand equivalent to the spore volume and $200 \mu \mathrm{l}$ of extract buffer $(0.4 \mathrm{M} \mathrm{NaCl}, 10 \mathrm{mM}$ Tris- $\mathrm{HCl}[\mathrm{pH}=8]$, and $2 \mathrm{mM}$ EDTA $[\mathrm{pH}=8]$ ) were added, and the mixture was ground with a plastic pestle for 10 to $15 \mathrm{~min}$. After adding $300 \mu \mathrm{l}$ of extraction buffer and $5 \mu \mathrm{l}$ of proteinase $\mathrm{K}$, and mixed gently, the mixture was incubated at $65^{\circ} \mathrm{C}$ for $2 \mathrm{~h}$. After adding $750 \mu \mathrm{l}$ of phenol-chloroformisoamylalcohol $(25: 24: 1, \mathrm{pH}>7.8)$ and vortexing, the mixture was centrifuged for $3 \mathrm{~min}$ at $13,000 \mathrm{rpm}$ at $4^{\circ} \mathrm{C}$. The upper aqueous phase was transferred to a clean tube, added with $300 \mu \mathrm{l}$ of chloroform and vortexed, and the mixture was centrifuged for $3 \mathrm{~min}$ at 13,000 rpm and $4{ }^{\circ} \mathrm{C}$. The upper aqueous phase was transferred to a clean tube and added with $750 \mu \mathrm{l}$ of isopropanol; and the solution was kept at $-20^{\circ} \mathrm{C}$ overnight to precipitate DNA. After centrifuging for $30 \mathrm{~min}$ at $13,000 \mathrm{rpm}$ and discarding the upper aqueous phase, the DNA pellet was washed with 75 and $95 \%$ ethanol. After drying for $2 \mathrm{~h}$ in a chemical hood, DNA was dissolved in $50 \mu \mathrm{l}$ of $1 \times \mathrm{TE}$ buffer. A total of $1.0 \mathrm{ml}$ of RNase A at $20 \mu \mathrm{g} / \mathrm{ml}$ was added to the DNA solution and incubated at $37^{\circ} \mathrm{C}$ for $30 \mathrm{~min}$ to digest RNA. The RNase was removed, and purified DNA was dissolved in TE buffer by precipitating, centrifuging, and resolving as described above. DNA concentration was determined with a ND-1000 spectrophotometer (Bio-Rad, CA), and the DNA solution was diluted to $50 \mathrm{ng} / \mathrm{ml}$ for use in polymerase chain reaction (PCR) tests with SSR markers.

SSR primers, PCR amplification, electrophoresis, and data analyses. Ninety-two pairs of $P$. striiformis $\mathrm{f}$. sp. tritici SSR primers (Supplementary Table S2) were screened for useful markers. Among the 92 primers, 27 were previously published (Enjalbert et al. 2002; Bahri et al. 2009; Chen et al. 2009a; Cheng et al. 2012) and 65 were designed by our lab. The forward primers were fluorescently $5^{\prime}$-labeled. These primers were synthesized by Shanghai Sangon Company (Shanghai, China). PCR reactions were performed in a $\mathrm{S} 1000$ Thermal Cycler (Bio-Rad) in a $25 \mu \mathrm{l}$ volume comprised of $1.0 \mu \mathrm{l}$ of DNA $(50 \mathrm{ng} / \mu \mathrm{l}), 2.5 \mu \mathrm{l}$ of $10 \times$ reaction buffer $\left(\mathrm{Mg}^{2+}\right.$ free $), 2.0 \mu \mathrm{l}$ of $\mathrm{Mg}^{2+}(25 \mathrm{mM}), 0.5 \mu \mathrm{l}$ of dNTPs $(10 \mathrm{mM})$, $0.5 \mu \mathrm{l}$ of each primer $(10 \mathrm{mM}), 0.2 \mu \mathrm{l}$ of Taq DNA polymerase (5 unit/ $\mu \mathrm{l}$, TaKaRa, Japan), and $17.8 \mu \mathrm{l}$ of $\mathrm{dd}_{2} \mathrm{O}$. The PCR reaction was carried out under the following conditions: initial denaturation at $95^{\circ} \mathrm{C}$ for $3 \mathrm{~min} ; 10$ cycles of $95^{\circ} \mathrm{C}$ for $30 \mathrm{~s}$ denaturation, $63^{\circ} \mathrm{C}$ for $30 \mathrm{~s}$ with a $1{ }^{\circ} \mathrm{C}$ decrease per cycle annealing, and $72^{\circ} \mathrm{C}$ for $30 \mathrm{~s}$ extension; 20 cycles of $95^{\circ} \mathrm{C}$ for $30 \mathrm{~s}$ denaturation, $58^{\circ} \mathrm{C}$ for $30 \mathrm{~s}$ annealing, and $72^{\circ} \mathrm{C}$ for $30 \mathrm{~s}$ extension; and $72^{\circ} \mathrm{C}$ for $6 \mathrm{~min}$ final extension. PCR products were analyzed on an Applied Biosystems 3730xl DNA Analyzer (Applied Biosystems, Pittsburgh, PA). The lengths of the SSR amplicons were scored using GeneMarker (Holland and Parson 2011). Observed heterozygosity of SSR loci were analyzed with the software package Arlequin version 3.11 (Schneider et al. 2000). The correlation coefficient between VPs and SSR genotypes was calculated using NTSYS-pc (version 2.10) MXCOMP. Linkage maps were constructed using quantitative trait locus (QTL) Icimapping software (Zhang et al. 2010). In order to reduce the possible effect of clonal isolates from a single aecium or a single aecial cup, the duplicate isolates were eliminated from same aecia that had identical genotypes to determine the inheritance of avirulence/virulence and construct genetic linkages.

\section{RESULTS}

Segregation of virulences. After eliminating genotypically identical isolates from the initial 118 progeny isolates as identical isolates were clonal from some individual aecial cups, 82 unique isolates were obtained. From the 82 isolates, 24 VPs were identified (Table 1, Supplementary Table S3). Of the 24 VPs, VP 1 comprised of $31(37.8 \%)$ isolates had the same virulence/avirulence pattern as the parental isolate, and all other 23 VPs were different from that of the parental isolate in virulence/avirulence on 8 of the $24 \mathrm{Yr}$ gene lines (Table 1). Compared with the parental isolate, four VPs (VP 2 to VP 5), comprised of six isolates, had the same number of virulences; 10 VPs (VP 6 to VP 15), comprised of 22 isolates, had decreased numbers of virulences; and nine VPs (VP 16 to VP 24), comprised of 23 isolates, had increased numbers of virulences. The results showed that through sexual reproduction, a single isolate can generate a large number of races with a wide range of virulences, and more virulent races could be produced.

For individual virulences or avirulences, the parental isolate and all progeny isolates were all avirulent to resistance genes $\operatorname{Yr} 5, \operatorname{Yr} 8$, $Y r 15$, and $Y r T r 1$, but virulent to $Y r 1, Y r 2, Y r 7, Y r 9, Y r 10, Y r 17, Y r 24$, $Y r 25, Y r 26, Y r A, Y r E x p 2$, and $Y r V 23$, indicating the parental isolate was homozygous in avirulence to the former group of resistance genes, and homozygous in virulence to the latter group of resistance genes. Segregations were observed for avirulences to $\operatorname{Yr} 6, \operatorname{Yr} 43$, and $\mathrm{YrSP}$ and for virulences to $\mathrm{Yr} 4, \mathrm{Yr} 27, \mathrm{Yr} 28, \mathrm{Yr} 32$, and $\mathrm{Yr} 44$ (Table 1). Two examples of different reactions produced by the parental and some progeny isolates were illustrated in Figure 1.

The segregations of the 82 unique isolates best fit a 3 avirulent: 1 virulent ratio for the avirulence to $\operatorname{Yr} 6, \mathrm{Yr} 43$, and $\mathrm{YrSP}$ (Table 2). The virulences to $Y r 27$ and $Y r 28$ of the parental isolate best fit to a 1 avirulent:3 virulent ratio; and to $Y r 4, Y r 32$, and $Y r 44$ best fit to 1 avirulent: 15 virulent ratio. The results indicated that the parental isolate had one dominant gene each for avirulence to $\mathrm{Yr} 6, \mathrm{Yr} 43$, and

TABLE 1. Virulence patterns of the parental (Pinglan 17-7) and progeny isolates of Puccinia striiformis f. sp. tritici on wheat $Y r$ gene lines

\begin{tabular}{|c|c|c|c|c|c|c|c|c|c|}
\hline \multirow{2}{*}{$\begin{array}{l}\text { Virulence } \\
\text { phenotypes }^{\text {a }}\end{array}$} & \multirow{2}{*}{$\begin{array}{l}\text { Number } \\
\text { of } \\
\text { isolates }\end{array}$} & \multicolumn{8}{|c|}{$\begin{array}{c}\text { Avirulence (A) and virulence (V) of parental and } \\
\text { progeny isolates of } P \text {. striiformis f. sp. tritici on } \\
\text { wheat lines with } Y r \text { genes }\end{array}$} \\
\hline & & Yr6 & $\operatorname{Yr} 43$ & $\operatorname{YrSP}$ & Yr4 & Yr27 & $\operatorname{Yr} 28$ & Yr32 & Yr44 \\
\hline \multicolumn{10}{|c|}{$\begin{array}{l}\text { Parental isolate } \\
\quad \text { (Pinglan 17-7) }\end{array}$} \\
\hline 1 & 1 & A & A & A & V & V & V & V & $\mathrm{V}$ \\
\hline \multicolumn{10}{|c|}{$\begin{array}{r}\text { Progeny isolates } \\
\text { (82 isolates })\end{array}$} \\
\hline 1 & 31 & A & A & A & V & V & V & V & V \\
\hline 2 & 1 & A & A & V & V & A & V & V & $\mathrm{V}$ \\
\hline 3 & 1 & V & A & A & A & V & V & V & V \\
\hline 4 & 3 & A & A & V & V & V & A & $\mathrm{V}$ & $\mathrm{V}$ \\
\hline 5 & 1 & V & $\mathrm{V}$ & A & V & A & A & V & V \\
\hline 6 & 6 & A & A & A & V & V & A & V & V \\
\hline 7 & 2 & A & A & A & V & V & V & V & A \\
\hline 8 & 2 & A & A & A & A & V & V & V & V \\
\hline 9 & 1 & A & A & A & V & V & V & A & V \\
\hline 10 & 1 & V & A & A & A & V & V & A & V \\
\hline 11 & 6 & A & A & A & $\mathrm{V}$ & A & $\mathrm{V}$ & $\mathrm{V}$ & $\mathrm{V}$ \\
\hline 12 & 1 & A & A & A & $\mathrm{V}$ & A & A & V & $\mathrm{V}$ \\
\hline 13 & 1 & A & A & A & V & V & A & A & $\mathrm{V}$ \\
\hline 14 & 1 & A & A & A & V & A & V & A & V \\
\hline 15 & 1 & A & A & A & V & A & V & V & A \\
\hline 16 & 4 & V & $\mathrm{V}$ & A & V & V & A & $\mathrm{V}$ & V \\
\hline 17 & 3 & $\mathrm{~V}$ & A & A & V & V & V & $\mathrm{V}$ & V \\
\hline 18 & 1 & $\mathrm{~V}$ & $\mathrm{~V}$ & V & A & V & $\mathrm{V}$ & A & V \\
\hline 19 & 2 & V & V & A & V & V & V & A & V \\
\hline 20 & 3 & A & A & $\mathrm{V}$ & V & V & $\mathrm{V}$ & V & V \\
\hline 21 & 2 & $\mathrm{~V}$ & $\mathrm{~V}$ & A & $\mathrm{V}$ & A & $\mathrm{V}$ & V & $\mathrm{V}$ \\
\hline 22 & 4 & $\mathrm{~V}$ & $\mathrm{~V}$ & A & V & V & $\mathrm{V}$ & $\mathrm{V}$ & $\mathrm{V}$ \\
\hline 23 & 1 & V & A & V & V & $\mathrm{V}$ & V & V & $\mathrm{V}$ \\
\hline 24 & 4 & $\mathrm{~V}$ & $\mathrm{~V}$ & V & $\mathrm{V}$ & $\mathrm{V}$ & $\mathrm{V}$ & $\mathrm{V}$ & $\mathrm{V}$ \\
\hline
\end{tabular}

a Progeny isolates were separated on 8 of the $24 \mathrm{Yr}$ gene lines. Parental isolate and progeny isolates were all homozygous avirulent on $\operatorname{Yr} 5, \operatorname{Yr} 8, \operatorname{Yr} 15$, and YrTr1 and homozygous virulent on $\operatorname{Yr} 1, \mathrm{Yr} 2, \mathrm{Yr} 7, \mathrm{Yr} 9, \mathrm{Yr} 10, \mathrm{Yr} 17, \mathrm{Yr} 24$, Yr25, Yr26, YrA, YrExp2, and YrV23. 
YrSP; one recessive gene for avirulence (or a dominant gene for virulence) to $\mathrm{Yr} 27$ and $\mathrm{Yr} 28$; and two complementary recessive genes for avirulence (or two independent dominant genes for virulence) to $\mathrm{Yr} 4, \mathrm{Yr} 32$, and $\mathrm{Yr} 44$.

Among all 24 possible pair-wise comparisons among the eight segregated avirulence ( $A v r)$ and virulent ( $a v r)$ genes, genes in only two pairs, Avr6 and Avr44 and avr4 and avr32, were found dependent; and genes in the remaining 26 pairs were independent (Table 3). The results indicated a close linkage between Avr6 and Avr44, and between $a v r 4$ and $a v r 32$, but not among other virulence or avirulence genes.

Segregation of SSR markers and linkage maps. Of 92 primer pairs screened, 13 produced codominant amplicons in the parental isolate that segregated among in the selfed progeny population (Supplementary Table S4). Two examples of SSR markers are shown in Figure 2. Based on the 13 SSR markers, 82 multilocus genotypes (MLGs) were identified from the 82 unique isolates after clonal correction. The heterozygosity of the 13 SSR loci ranged from 42 to $68 \%$ with a mean of $54 \%$. Of the 13 SSR markers, seven (Scaffold729-261726, C20054-10711, C20772-1684, Scaffold452241300, SUNIPst10-06, C22298-60119, and C20508-14614) fit a 1:2:1 ratio for homozygous (a1a1):heterozygous (a1a2):homozygous (a2a2) genotypes for each locus ( $P=0.07$ to 0.99$)$; while the remaining six

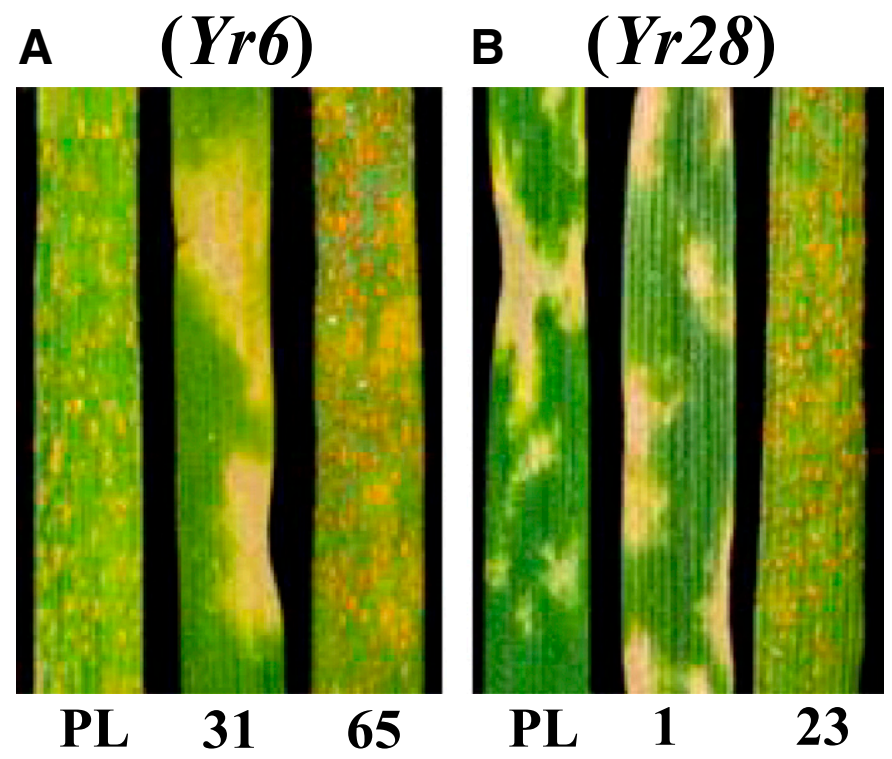

Fig. 1. Infection types of the parental isolate (PL; Pinglan 17-7) and its selfed progeny isolates $(1,23,31$, and 65$)$ on wheat near-isogenic lines of $\mathbf{A}, \operatorname{Yr} 6$ and B, $\operatorname{Yr} 28$.

TABLE 2. Infection types, segregation of avirulences/virulences in the progeny isolates derived from selfing parental isolate Pinglan 17-7 of Puccinia striiformis f. sp. tritici on wheat lines with $Y r$ genes, and probability values of $\chi^{2}$ tests for goodness of fit of the observed isolates in avirulent and virulent classes to theoretical ratios

\begin{tabular}{|c|c|c|c|c|c|}
\hline \multirow{2}{*}{$\begin{array}{l}\text { Wheat line } \\
\text { with } Y r \text { gene }\end{array}$} & \multirow{2}{*}{$\begin{array}{l}\text { Infection type of } \\
\text { parental isolate }\end{array}$} & \multicolumn{2}{|c|}{$\begin{array}{l}\text { Observed number } \\
\text { of progeny isolates }\end{array}$} & \multirow{2}{*}{$\begin{array}{l}\text { Expected } \\
\text { ratio }\end{array}$} & \multirow[b]{2}{*}{$P$} \\
\hline & & Avirulent & Virulent & & \\
\hline $\operatorname{Yr} 6$ & 2 & 58 & 24 & $3: 1$ & 0.37 \\
\hline Yr43 & 2 & 65 & 17 & $3: 1$ & 0.37 \\
\hline$Y r S P$ & 1 & 69 & 13 & $3: 1$ & 0.06 \\
\hline Yr27 & 9 & 13 & 69 & $1: 3$ & 0.06 \\
\hline $\operatorname{Yr} 28$ & 9 & 16 & 66 & $1: 3$ & 0.25 \\
\hline $\mathrm{Yr} 4$ & 9 & 5 & 77 & $1: 15$ & 0.95 \\
\hline Yr32 & 9 & 7 & 75 & $1: 15$ & 0.39 \\
\hline $\operatorname{Yr} 44$ & 9 & 3 & 79 & $1: 15$ & 0.33 \\
\hline
\end{tabular}

markers did not fit the ratio $(P<0.05)$. The data indicated that some of the SSR markers were suitable for constructing molecular maps.

One linkage group consisting of 10 SSR markers and eight avirulence/virulence genes was constructed using QTL Icimapping software (Fig. 3). Recessive avirulence (or dominant virulence genes) avr4, avr32, avr44, and $a v r 27$ were more closely linked than two others, and dominant avirulence genes Avr43 and Avr6 were more closely linked to each other just in $7.37 \mathrm{cM}$. The remaining

TABLE 3. Probability values of $\chi^{2}$ tests for independence of genes for virulence/avirulence in the progeny population derived from selfing isolate Pinglan 17-7 on barberry plants

\begin{tabular}{|c|c|c|c|c|c|c|c|}
\hline \multirow{3}{*}{$\begin{array}{l}A v r \text { or } \\
a v r \text { gene }\end{array}$} & \multicolumn{7}{|c|}{$P^{\mathrm{a}}$} \\
\hline & \multicolumn{2}{|c|}{ Avirulence $(A v r)$} & \multicolumn{5}{|c|}{ Virulence $(a v r)$} \\
\hline & Avr43 & $A v r S P$ & $a v r 4$ & $a v r 27$ & $a v r 28$ & avr32 & $a v r 44$ \\
\hline Avr6 & 0.00 & 0.13 & 0.33 & 0.18 & 0.55 & 0.11 & 0.43 \\
\hline Avr43 & & 0.11 & 0.94 & 0.25 & 0.45 & 0.34 & 0.63 \\
\hline$A v r S P$ & & & 0.29 & 0.06 & 0.11 & 0.21 & 0.20 \\
\hline avr4 & & & & 0.23 & 0.50 & 0.02 & 0.79 \\
\hline avr27 & & & & & 0.17 & 0.21 & 0.16 \\
\hline avr 28 & & & & & & 0.51 & 0.48 \\
\hline avr32 & & & & & & & 0.22 \\
\hline
\end{tabular}

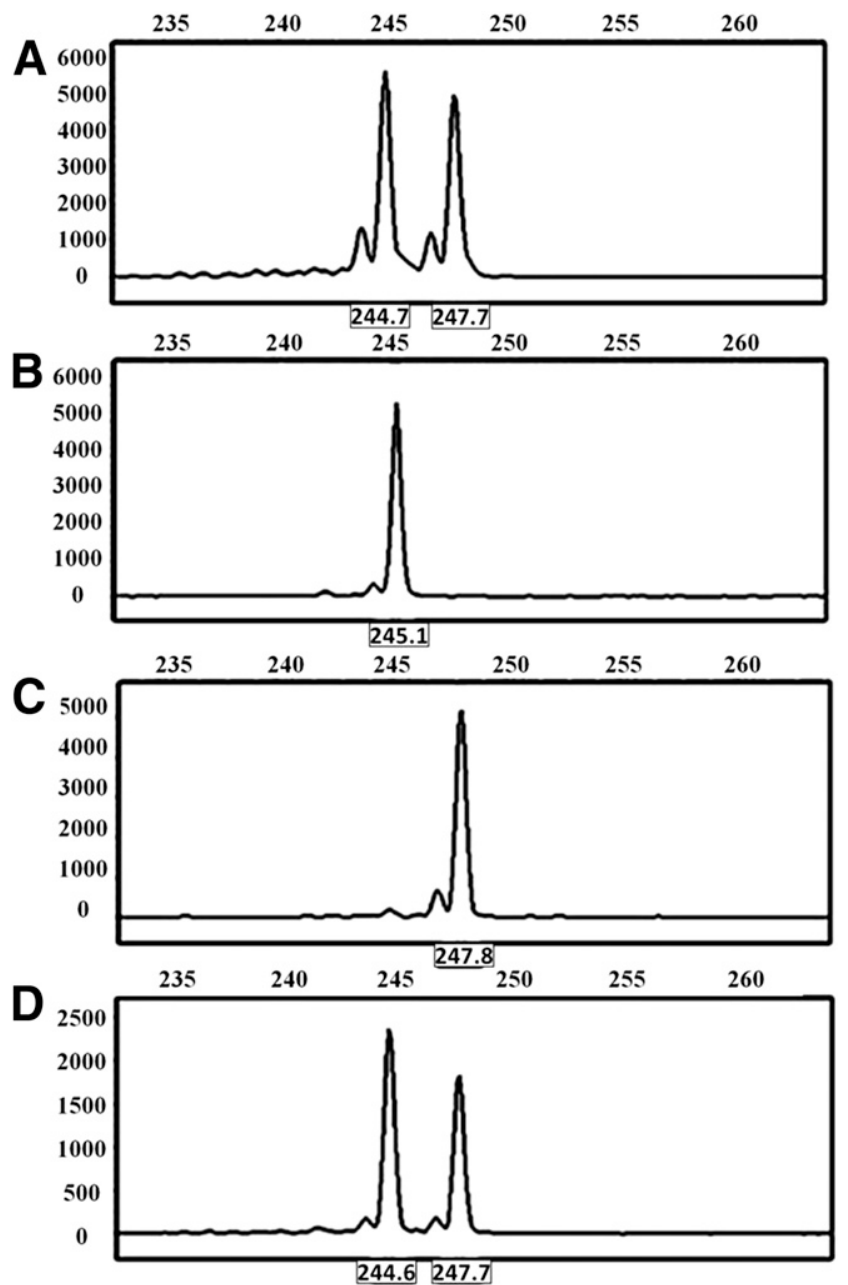

Fig. 2. Two alleles of the simple sequence repeat marker C20508-14614 loci in isolates of Puccinia striiformis f. sp. tritici separated using an Applied Biosystems 3730xl DNA Analyzer. A, The parental isolate (Pinglan 17-7) and progeny isolates $\mathbf{B}, 1, \mathbf{C}, 11$, and $\mathbf{D}, 13$. 
three markers were not linked to any other markers or avirulence locus, indicating the possibility of different chromosomes.

\section{DISCUSSION}

In the present study, we developed a progeny population comprised of 82 unique isolates through selfing $P$. striiformis $\mathrm{f}$. sp. tritici isolate Pinglan 17-7 on barberry plants. Using the segregating population, we determined homozygosity and heterozygosity of the parental isolate at 24 virulence/avirulence loci, and inheritance of 8 loci. We constructed the first linkage map for $P$. striiformis f. sp. tritici, although it is preliminary. The results show that a selfed progeny population is suitable for genetic studies for the largely asexually produced fungal pathogen.

From the 82 progeny isolates, we identified 24 VPs (pathotypes), some of which had a wider virulence spectrum. The results show that sexual reproduction could produce not only a large number of pathotypes, but pathotypes more virulent than the original isolate. In fact, about $18.3 \%$ of the progeny isolates had wider virulent spectra than the parental isolate, even one isolate combined all of eight virulences which segregated in the progeny population. The results of the present study support the hypothesis that sexual reproduction can produce higher genetic diversity than asexual reproduction (McDonald and Linde 2002). In the present study, the large number of pathotypes and MLGs produced by one isolate was obtained under controlled conditions. However, it is not clear if sexual reproduction is important under natural conditions. In the United States, no $P$. striiformis $\mathrm{f}$. sp. tritici aecia were identified positively and all aecia on barberry plants were identified as $P$. graminis $\mathrm{f}$. sp. tritici or related formae speciales on grasses (Wang et al. 2015a). Teliospore degradation and plant phenology were attributed to the lack of $P$. striiformis $\mathrm{f}$. sp. tritici sexual reproduction (Wang and

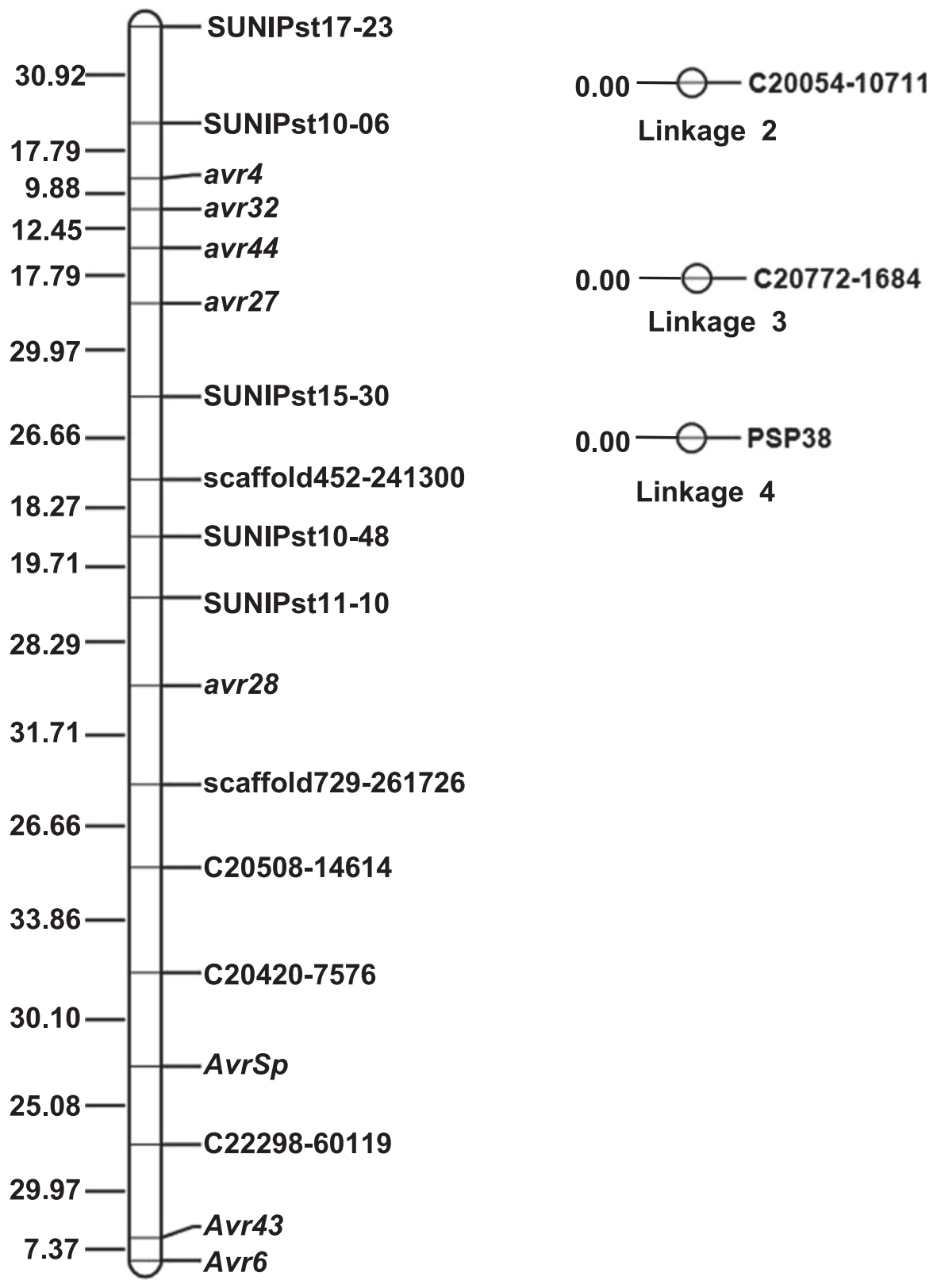

Linkage 1

Fig. 3. Linkage maps constructed with simple sequence repeat markers and avirulence (Avr) and virulence (avr) data of 82 progeny isolates developed through selfing isolate Pinglan 17-7 of Puccinia striiformis f. sp. tritici using quantitative trait locus Icimapping software. 
Chen 2015). However, in northwestern China, weather conditions may allow $P$. striiformis $\mathrm{f}$. sp. tritici teliospores to survive winter and infect barberry plants in spring (Wang et al. 2015a), as shown by $P$. striiformis f. sp. tritici aecia recovered from naturally infected barberry plants (Wang et al. 2015b; Zhao et al. 2013). In the previous studies, 20 P. striiformis $\mathrm{f}$. sp. tritici isolates were obtained from naturally infected barberry plants at a very low frequency in 2013 and 2014 in China, respectively (Wang et al. 2015b; Zhao et al. 2013), which provided direct evidence that $P$. striiformis f. sp. tritici sexual reproduction exists in China under natural conditions. Among the 20 P. striiformis $\mathrm{f}$. sp. tritici isolates, two showed an overall virulence pattern similar to the predominant $P$. striiformis f. sp. tritici race CYR32 in wheat fields (Wang et al. 2015b), indicating that the sources of inoculum (teliospores on wheat straw) for infection of the barberry plants were from the P. striiformis $\mathrm{f}$. sp. tritici population in the nearby wheat fields. Furthermore, 200 single-uredinium isolates derived from the 20 P. striiformis $\mathrm{f}$. $\mathrm{sp}$. tritici isolates showed high virulence diversity (Wang et al. 2015b; Zhao et al. 2013). This finding demonstrates that such high virulence diversity for the $P$. striiformis $\mathrm{f}$. sp. tritici isolates from infected barberry plants may be due to natural sexual reproduction on alternate hosts, similar to the results of the present study through selfing a single isolate on barberry under controlled condition. However, the role of sexual reproduction in providing initial inoculum and generating diversity for $P$. striiformis f. sp. tritici should be further confirmed for different regions in the world.

Because of discovery of the alternate hosts for P. striiformis f. sp. tritici, sexual reproduction under controlled conditions becomes an important approach for studying genetics of $P$. striiformis $\mathrm{f}$. sp. tritici (Rodriguez-Algaba et al. 2014; Wang et al. 2012). Through selfing a U.S. $P$. striiformis f. sp. tritici isolate of race PST-127, a most virulent race (Chen et al. 2010; Wan and Chen 2012), Wang et al. (2012) identified homozygous virulences to $Y r 1, Y r 2$, and $Y r 9$ and homozygous avirulence to $Y r 5, Y r 15, Y r 24, Y r 32$, and $Y r S P$. In their study, avirulences to $\operatorname{Yr} 6, \operatorname{Yr} 7, \operatorname{Yr} 8, \operatorname{Yr} 19, \operatorname{Yr} 27, \operatorname{YrExp} 2$, and YrTye were controlled by a dominant gene; to $Y r 44$ by two dominant genes; to $\operatorname{Yr} 10, \operatorname{Yr} 17, \operatorname{YrTr} 1$, and $\operatorname{YrExp} 1$ by one recessive gene; and to $Y r 43$ and an unknown gene by two recessive genes. Our data agree with their data in homozygous avirulences to $\operatorname{Yr} 5$ and $\mathrm{Yr} 15$, homozygous virulences to $Y r 1, Y r 2$, and $Y r 9$, and heterozygous avirulences/virulences to $Y r 6, Y r 27, Y r 43$, and $Y r 44$. We also found that avirulence to $\operatorname{Yr} 6$ was controlled by a dominant gene. In contrast, we found in the present study that $Y r 43$ avirulence is controlled by a dominant gene, $Y r 27$ avirulence is controlled by a recessive gene, $Y r 44$ avirulence by two recessive genes. The different results from these studies for the avirulences/virulences to the same $\mathrm{Yr}$ genes suggest that virulence/avirulence to a single $\mathrm{Yr}$ gene can be either dominant or recessive, and can be controlled by different genes. In general, our results are in agreement with the one-for-one gene model (Flor 1965) with some exceptions. Interactions of one-for-more genes were previously reported for other rust fungal species as well (Statler 1977, 1979, 1990, 2000). The exceptions for the typical gene-for-gene model can be attributed to two reasons. One is the presence of an additional modifier gene; another is that some of the wheat lines may have more than one gene for resistance, or two virulence genes are required to overcome one resistance gene (Samborski and Dyck 1976; Statler 1979; Zambino et al. 2000). Therefore, more studies are needed to determine the inheritance modes of virulence/avirulence in general and also for particular virulences or avirulences.

Knowledge about which genes should be used in breeding programs could be obtained from studies on inheritance of virulence/avirulence. Virulence changes would happen in heterozygous population more rapidly than in a homozygous one (Statler 1977) as one step mutation is required for changing a heterozygous isolate from dominant resistance while two steps of mutation are required for changing a homozygous resistance to susceptible. Pinglan 17-7 was found heterozygous at 8 of the 24 marker loci tested. Based on this discussion and the data in the present study, $Y r 5, Y r 8, Y r 15$, and $Y r \operatorname{Tr} 1$ could last longer than $\operatorname{Yr} 6, \operatorname{Yr} 43$, and $\operatorname{YrSP}$. However, virulences to Yr6, Yr8, Yr43, YrSP, and YrTrl have been identified in the P. striiformis f. sp. tritici population in China (Chen et al. 2009b; Sharma-Poudyal et al. 2013; Zhan et al. 2012), although these genes are effective in the present study. In the present study, we used only one $P$. striiformis f. sp. tritici isolate. More isolates representing diverse races should be studied for homozygous or heterozygous Avr or vir genes to get the knowledge of homozygosity or heterozygosity for Avrlavr genes studied in the present study and other genes in the natural $P$. striiformis f. sp. tritici population. For breeding programs, it is better to combine resistance genes that are still effective against all known races, and combine effective all-stage resistance with durable high-temperature adult-plant resistance genes (Chen 2013). For effective resistance genes, it is useful to know if the corresponding avirulences in the pathogen population are homozygous or heterozygous to assess their relative durability.

In the present study, we determined the genetic diversity in the progeny population using SSR markers. The number of genotypes was very high, and much higher than the virulence phenotype. The correlation coefficient between the virulence phenotypes and genotypes was low and insignificant. The low coefficient was expected as the SSR markers were not based on virulence genes. Using the limited number of SSR markers, we were able to construct a linkage map, the first genetic map for $P$. striiformis f. sp. tritici. More markers are needed to fill the big gaps between some of the markers and avirulence genes, so as to potentially clone avirulence/virulence genes using a map-based cloning approach.

\section{ACKNOWLEDGMENTS}

This work was supported by the National Key Basic Research Program of China (2013CB127700), International Science \& Technology Cooperation Program of China (2011DFG32990), the Nature Science Foundation of China (31371882, 31271986), Modern Agro-industry Technology Research System in China (CARS-3-1-11), and the 111 Project from the Ministry of Education of China (B07049).

\section{LITERATURE CITED}

Ali, S., Leconte, M., Walker, A.S., Enjalbert, J., and de Vallavieille-Pope, C. 2010. Reduction in the sex ability of worldwide clonal populations of Puccinia striiformis f. sp. tritici. Fungal Genet. Biol. 47:828-838.

Aljanabi, S. M., and Martinez, I. 1997. Universal and rapid salt-extraction of high quality genomic DNA for PCR-based techniques. Nucleic Acids Res. 25:4692-4693

Bahri, B., Leconte, M., de Vallavieille-Pope, C., and Enjalbert, J. 2009. Isolation of ten microsatellite loci in an EST library of the phytopathogenic fungus Puccinia striiformis f. sp. tritici. Conserv. Genet. 10: 1425-1428.

Chen, C. Q., Zheng, W. M., Huang, L. L., Lu, N. H., and Kang, Z. S. 2009a. Isolation of microsatellite loci from expressed sequence tags (ESTs) library of Puccinia striiformis f. sp. tritici. Mol. Ecol. Resour. 9:236-238.

Chen, W. Q., Wu, L. R., Liu, T. G., Xu, S. C., Jin, S. L., Peng, Y. L., and Wang, B. T. 2009b. Race dynamics, diversity, and virulence evolution in Puccinia striiformis $\mathrm{f}$. sp. tritici, the causal agent of wheat stripe rust in China from 2003 to 2007. Plant Dis. 93:1093-1101.

Chen, X. M. 2005. Epidemiology and control of stripe rust [Puccinia striiformis f. sp. tritici] on wheat. Can. J. Plant Pathol. 27:314-337.

Chen, X. M. 2013. Review article: High-temperature adult-plant resistance, key for sustainable control of stripe rust. Am. J. Plant Sci. 4:608-627.

Chen, X. M., Penman, L., Wan, A. M., and Cheng, P. 2010. Virulence races of Puccinia striiformis f. sp. tritici in 2006 and 2007 and development of wheat stripe rust and distributions, dynamics, and evolutionary relationships of races from 2000 to 2007 in the United States. Can. J. Plant Pathol. 32:315-333.

Cheng, P., and Chen, X. M. 2014. Virulence and molecular analyses support asexual reproduction of Puccinia striiformis f. sp. tritici in the U.S. Pacific Northwest. Phytopathology 104:1208-1220.

Cheng, P., Chen, X. M., Xu, L. S., and See, D. R. 2012. Development and characterization of expressed sequence tag-derived microsatellite markers for the wheat stripe rust fungus Puccinia striiformis f. sp. tritici. Mol. Ecol. Resour. 12:779-781. 
Duan, X., Tellier, A.,Wan, A., Leconte, M., de Vallavielle-Pope, C., and Enjalbert, J. 2010. Puccinia striiformis f. sp. tritici presents high diversity and recombination in the over-summering zone of Gansu, China. Mycologia 102:44-53.

Enjalbert, J., Duan, X., Giraud, T., Vautrin, D., de Vallavieille-Pope, C., and Solignac, M. 2002. Isolation of twelve microsatellite loci, using an enrichment protocol, in the phytopathogenic fungus Puccinia striformis $\mathrm{f}$. $\mathrm{sp}$. tritici. Mol. Ecol. Notes 2:563-565.

Flor, H. H. 1965. Tests for allelism of rust-resistance genes in flax. Crop Sci. $5: 415-418$.

Gassner, G., and Straib, W. 1932. Die Bestimmung der biologischen Rassen des Weizengelbrostes (Puccinia glumarum f. sp. tritici (Schmidt) Erikss; et Henn.). Arbeitenaus Biologischen Reichsanstalt Land Forstwirtschaft Berl. 20:141-163.

Godard, M. V. 1976. Cytological studies of Puccinia striiformis Westend. (yellow rust of wheat). Trans. Br. Mycol. Soc. 66:433-437.

Han, D. J., Wang, Q. L., Chen, X. M., Zeng, Q. D., Wu, J. H., Xue, W. B., Zhan, G. M., Huang, L. L., and Kang, Z. S. 2015. The emerging Yr26virulent races of Puccinia striiformis f. sp. tritici are threatening the wheat production in the Sichuan Basin, China. Plant Dis. 99:754-760.

Holland, M. M., and Parson, W. 2011. GeneMarker HID: A reliable software tool for the analysis of forensic STR data. J. Forensic Sci. 56:29-35.

Jin, Y., Szabo, L. J., and Carson, M. 2010. Century-old mystery of Puccinia striiformis life history solved with the identification of Berberis as an alternate host. Phytopathology 100:432-435.

Kosman, E., and Leonard, K. J. 2007. Conceptual analysis of methods applied to assessment of diversity within and distance between populations with asexual or mixed mode of reproduction. New Phytol. 174: 683-696.

Li, Z. Q. 1980. The variation of wheat variety resistance to stripe rust in China and the way of its solution. Sci. Agric. Sin. 3:72-77. (in Chinese)

Line, R. F., and Qayoum, A. 1992. Virulence, aggressiveness, evolution and distribution of races of Puccinia striiformis (the cause of stripe rust of wheat) in North America, 1968-87. U.S. Department of Agriculture Technical Bulletin No. 1788 .

Little, R., and Manners, J. G. 1967. Production of new physiologic races in Puccinia striiformis (yellow rust) by heterokaryosis. Nature 213:422.

Liu, B., Chen, X. M., and Kang, Z. S. 2012. Gene sequencing reveals heterokaryotic variations and evolutionary mechanisms in Puccinia striiformis. Open J. Genomics 1:1.

Mboup, M., Leconte, M., Gautier, A., Wan, A. M., Chen, W. Q., de Vallavielle-Pope, C., and Enjalbert, J. 2009. Evidence of genetic recombination in wheat yellow rust population of a Chinese over-summering area. Fungal Genet. Biol. 46:299-307.

McDonald, B. A., and Linde, C. 2002. Pathogen population genetics, evolutionary potential, and durable resistance. Annu. Rev. Phytopathol. 40: 349-379.

McDowell, J. M., and Woffenden, B. J. 2003. Plant disease resistance genes: Recent insights and potential applications. Trends Biotechnol. 21:178-183.

Newton, M., Johnson, T., and Brown, A. M. 1930. A preliminary study on the hybridization of physiologic forms of Puccinia graminis tritici. Sci. Agric. 10:721-731.

Park, R. F., and Wellings, C. R. 2012. Somatic hybridization in the Uredinales. Annu. Rev. Phytopathol. 50:219-239.

Rodriguez-Algaba, J., Walter, S., Sørensen, C. K., Hovmøller, M. S., and Justesen, A. F. 2014. Sexual structures and recombination of the wheat rust fungus Puccinia striiformis on Berberis vulgaris. Fungal Genet. Biol. 70: $77-85$

Samborski, D. J., and Dyck, P. L. 1976. Inheritance of virulence in Puccinia recondite on six backcross lines of wheat with single genes for resistance to leaf rust. Can. J. Bot. 54:1666-1671.

Schneider, S., Roessli, D., and Excoffier, L. 2000. Arlequin Ver. 2000: A software for population genetics data analysis. Genetics and Biometry Laboratory, University of Geneva.

Sharma-Poudyal, D., Chen, X. M., Wan, A. M., Zhan, G. M., Kang, Z. S., Cao, S. Q., Jin, S. L., Morgounov, A., Akin, B., Mert, Z., Shah, S. J. A., Bux, H., Ashraf, M., Sharma, R. C., Madariaga, R., Puri, K. D., Wellings, C., Xi, K. Q., Wanyera, R., Manninger, K., Ganzález, M. I., Koyda, M., Sanin, S., and Patzek, L. J. 2013. Virulence characterization of international collections of the wheat stripe rust pathogen, Puccinia striiformis f. sp. tritici. Plant Dis. 97:379-386.

Statler, G. D. 1977. Inheritance of virulence of culture 73-47 Puccinia recondita. Phytopathology 67:906-908.
Statler, G. D. 1979. Inheritance of pathogenicity of culture 70-1, race 1, of Puccinia recondite tritici. Phytopathology 69:661-663.

Statler, G. D. 1985. Mutations affecting virulence in Puccinia recondita. Phytopathology 75:565-567.

Statler, G. D. 1990. Inheritance of pathogenicity of progeny from an $F_{1}$ culture of Melampsora lini. J. Phytopathol. 128:184-190.

Statler, G. D. 2000. Inheritance of virulence of Puccinia triticina culture X47, the F1 of the cross 71-112 × 70-1. Can. J. Plant Pathol. 22:276-279.

Wan, A. M., and Chen, X. M. 2012. Virulence, frequency, and distribution of races of Puccinia striiformis f. sp. tritici and P. striiformis f. sp. hordei identified in the United States in 2008 and 2009. Plant Dis. 96:67-74.

Wan, A. M., Chen, X. M., and He, Z. H. 2007. Wheat stripe rust in China. Aust. J. Agric. Res. 58:605-619.

Wan, A. M., Zhao, Z. H., Chen, X. M., Jin, S. L., Jia, Q. Z., Yao, G., Yang, J. X., Wang, B. T., Li, G. B., Bi, Y. Q., and Yuan, Z. Y. 2004. Wheat stripe rust epidemic and virulence of Puccinia striiformis f. sp.tritici in China in 2002. Plant Dis. 88:896-904.

Wang, M. N., and Chen, X. M. 2013. First report of Oregon grape (Mahonia aquifolium) as an alternate host for the wheat stripe rust pathogen (Puccinia striiformis f. sp. tritici) under artificial inoculation. Plant Dis. 97:839.

Wang, M. N., and Chen, X. M. 2015. Barberry does not function as an alternate host for Puccinia striiformis f. sp. tritici in the U.S. Pacific Northwest due to teliospore degradation and barberry phenology. Plant Dis. 99:1500-1506.

Wang, M. N., Wan, A. M., and Chen, X. M. 2012. Genetic characterization of virulence/avirulence genes of Puccinia striiformis f. sp. tritici. American Phytopathological Society. http://www.apsnet.org/meetings/Documents/ 2012_Meeting_Abstracts/aps12abP81.htm

Wang, M. N., Wan, A. M., and Chen, X. M. 2015a. Barberry as alternate host is important for Puccinia graminis f. sp. tritici but not for Puccinia striiformis f. sp. tritici in the U.S. Pacific Northwest. Plant Dis. 99:1507-1516.

Wang, Z. Y., Zhao, J., Chen, X. M., Peng, Y. L., Ji, J. J., Lv, Y. J., Zhao, S. L., Huang, L. L., and Kang, Z. S. 2015b. Virulence variations of Puccinia striiformis f. sp. tritici isolates collected from Berberis spp. in China. Plant Dis. doi:10.1094/PDIS-12-14-1296-RE

Waterhouse, W. L. 1929. A preliminary account of the origin of two new Australian physiologic forms of Puccinia graminis tritici. Proc. Linn. Soc. N. S. W. 54:96-106.

Wellings, C. R. 2011. Global status of stripe rust: A review of historical and current threats. Euphytica 179:129-141.

Zambino, P. J., Kubelik, A. R., and Szabo, L. J. 2000. Gene action and linkage of avirulence genes to DNA markers in the rust fungus Puccinia graminis. Phytopathology 90:819-826.

Zhan, G. M., Chen, X. M., Kang, Z. S., Huang, L. L., Wang, M. N., Wan, A. M., Cheng, P., Cao, S. Q., and Jin, S. L. 2012. Virulence and molecular comparison of Puccinia striiformis f. sp. tritici populations in China and the United States. Fungal Biol. 116:643-653.

Zhan, G. M., Wang, F. P., Chen, X. M., Wan, C. P., Han, Q. M., Huang, L. L., and Kang, Z. S. 2015. Virulence and molecular diversity of the Puccinia striiformis f. sp. tritici population in Xinjiang in relation to other regions of western China. Plant Dis. doi:10.1094/PDIS-11-14-1142-RE

Zhang, L. Y., Wang, S. Q., Li, H. H., Deng, Q. M., Zheng, A. P., Li, S. C., Li, P., Li, Z. G., and Wang, J. K. 2010. Effects of missing marker and segregating distortion on QTL mapping in $\mathrm{F}_{2}$ populations. Theor. Appl. Genet. 121:1071-1082

Zhao, J., Wang, L., Wang, Z. Y., Zhang, H. C., Yao, J. N., Zhan, G. M., Chen, W., Huang, L. L., and Kang, Z. S. 2013. Identification of eighteen Berberis species as alternate hosts of Puccinia striiformis f. sp. tritici and virulence variation in the pathogen isolates from natural infection of barberry plants in China. Phytopathology 103:927-934.

Zhao, J., Zhang, H. C., Yao, J. N., Huang, L. L., and Kang, Z. S. 2011. Confirmation of Berberis spp. as alternate hosts of Puccinia striiformis f. sp. tritici on wheat in China. Mygosystema 30:895-900. (in Chinese)

Zheng, W. M., Huang, L. L., Huang, J. Q., Wang, X. J., Chen, X. M., Zhao, J., Guo, J., Zhuang, H., Qiu, C. Z., Liu, J., Liu, H. Q., Huang, X. L., Pei, G. L., Zhan, G. M., Tang, C. L., Cheng, Y. L., Liu, M. J., Zhang, J. S., Zhao, Z. T., Zhang, S. J., Han, Q. M., Han, D. J., Zhang, H. C., Zhao, J., Gao, X. N., Wang, J. F., Ni, P. X., Dong, W., Yang, L. F., Yang, H. M., Xu, J. R., Zhang, G. Y., and Kang, Z. S. 2013. High genome heterozygosity and endemic genetic recombination in the wheat stripe rust fungus. Nat. Commun. 4:2673.

Zheng, Z. L. 2011. Inducing factors of telial stage of Puccinia striiformis $\mathrm{f}$. sp. tritici. M.Sc. Thesis. The Institute of Plant Protection, Chinese Academy of Agriculture Science. (in Chinese) 